\title{
KESAKSIAN PEREMPUAN DALAM KONTRAK KEUANGAN DALAM KITAB-KITAB TAFSIR
}

\author{
Halimah B.
}

Fakultas Syariah dan Hukum UIN Alauddin Makassar

\begin{abstract}
In the commentaries both in classical commentaries and in modern and contemporary commentaries the commentators agree that women have the right to be witnesses in accounts payable transactions with men. However, they disagreed about the quantity of female witnesses, the classical interpreter refers to the textual approach of two female witnesses with one man. While modern and contemporary interpreters use a contextual approach, which can be one female witness with one male witness. They relate the sociohistorical context of the Qur'an, also to the present context. They also adhere to the rules of the Uthul Figh "al-hukmu yadurru ma'a al-illah wujuudan wa 'adaman". The testimony is based on professionalism and credibility, has nothing to do with gender. Thus, if women have intelligence in the economic field then their testimony it can be equated with the testimony of men, especially in the testimony of accounts payable, because in other verses the testimony does not mention gender classification, so if the verse is understood contextually (not normatively), it will certainly give birth to justice and gender equality.
\end{abstract}

\section{Keywords:}

Testimony, Witnesses, Women, Financial Contracts, Interpretation Books

\begin{abstract}
Abstrak
Dalam kitab-kitab tafsir baik dalam kitab tafsir klasik maupun kitab tafsir modern dan kontemporer para mufasirnya sepakat bahwa perempuan mempunyai hak menjadi saksi dalam transaksi utang piutang sama dengan laki-laki. Namun, mereka berbeda pendapat mengenai kuantitas saksi perempuan, mufassir klasik mengacu kepada pendekatan tekstual yakni dua orang saksi perempuan bersama satu orang laki-laki. Sementara mufassir modern dan kontemporer menggunakan pendekatan kontekstual, yakni bisa satu orang saksi perempuan bersama satu orang saksi laki-laki. Mereka mengaitkan konteks sosio-historis al-Qur'an, juga dengan konteks masa kini. Mereka juga berpegang kepada kaidah Ushul Fiqh "alhukmu yadurru ma'a al-illah wujuudan wa 'adaman". Kesaksian itu berdasarkan profesionalisme dan kredibilitas, tidak ada hubungannya
\end{abstract}




\begin{abstract}
dengan jenis kelamin. Dengan demikian, jika perempuan mempunyai kecerdasan dalam bidang ekonomi maka kesaksiannya boleh disamakan dengan kesaksian laki-laki khususnya dalam kesaksian transaksi utang piutang, karena dalam ayat-ayat yang lain tentang kesaksian tidak menyebutkan klasifikasi jenis kelamin. Dengan demikian jika ayat tersebut dipahami secara kontekstual (bukan normatif), tentu akan melahirkan keadilan dan kesetaraan gender.
\end{abstract}

\title{
Kata Kunci:
}

Kesaksian, Saksi, Perempuan, Kontrak Keuangan, Kitab-kitab Tafsir

\section{A. PENDAHULUAN}

$\mathrm{P}$ roblema kesaksian (syahädah) perempuan menjadi perdebatan yang hebat dalam teologi Islam, khususnya dalam masalah kontrak keuangan. Kesaksian perempuan dalam transaksi uang piutang, dua orang perempuan setara dengan kesaksian satu orang laki-laki. Ketentuan ini oleh Feminis dianggap diskriminasi terhadap perempuan. Perbedaan ini dianggap menjatuhkan kemuliaan perempuan, serta dapat menimbulkan rasa keraguan pada asas persamaan, merampas hak-haknya serta menghina keberadaannya.

Perdebatan masalah ini merujuk: Pertama; pada QS. al-Baqarah/2: 282. Kedua; mereka berpegang terhadap penegasan hadith Nabi saw. yang menjelaskan tentang perempuan kurang akal karena kesaksian dua perempuan sama dengan kesaksian seorang laki-laki."

Islam telah mengakui kecakapan perempuan secara lengkap berkenaan dengan pembagian tugas-tugasnya, dan hal itu tanpa membutuhkan kekuasaan tertentu baginya. Laki-laki dan perempuan sama-sama memiliki usaha dalam kehidupan ini, sebagimana dijelaskan dalam QS.Ali Imran/3:195 dan QS. al-Nisa'/4: 32.

Sebahagian berpandangan bahwa atas pertimbangan kesetaraan ini, ditemukan hikmah yang sempurna dan agung, karena syariat telah membedakan laki-laki dan perempuan dalam hak-hak dan kewajibannya. Semua itu bertujuan untuk menjelaskan perbedaan biologis dan psikologis masing-masing keduanya seperti halnya mahluk lainnya. Tujuan syariat Islam dalam penetapan hukum ini sejatinya adalah demi menjaga kemuliaan derajat kaum perempuan dan posisinya yang tinggi dapat terealisasi di dalam masyarakat. ${ }^{1}$

Dalam QS. al-Baqarah /2:282; dan Hadith Rasulullah tersebut kesaksian dua orang perempuan setara dengan kesaksian seorang laki-laki karena perempuan dipandang kurang akal, pelupa dan sering lalai. Pandangan ini ini masih menjadi perdebatan di kalangan para ilmuan, karena sebahagian mereka memahami penafsiran ayat secara tekstual dan lainnya dengan kontekstual. Karena itu perlu

${ }^{1}$ Fada 'Abdur Razak al-Qașir, al-Mar'ah al-Muslimah: Bayn al-Syari'ah al-Islamiyyah wa al-Adāîl alGharbiyyah (terj.), Wanita Muslimah Antara syariat Islam dan Budaya Barat ( Yogyakarta: Darussalam Offset, 2004), 148. 
dianalisa secara mendalam untuk mempeoleh penafsiran yang relevan dengan masa kini, sehingga keadilan dan kesetaraan jender dapat terwujud.

\section{B. PEMBAHASAN}

Kesaksian perempuan dalam transaksi utang piutang, dua perempuan setara dengan seorang laki-laki, atau dengan kata lain kesaksian perempuan setengah dari kesaksian perempuan. Hal tersebut merujuk dari penafsiran QS. al-Baqarah (2): 282 :

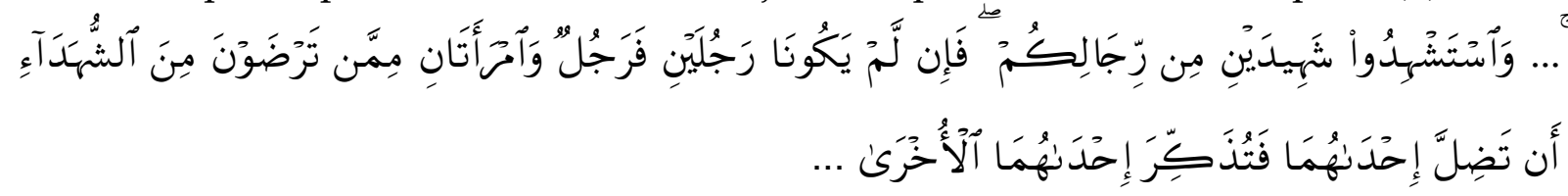

\section{Terjemahnya:}

...Dan persaksikanlah dengan dua orang saksi dari orang laki-laki (di antaramu). Jika tidak ada dua saksi laki-laki maka (boleh) seorang laki-laki dan dua orang perempuan dari saksisaksi yang kamu ridhai, supaya jika seorang lupa maka seorang lagi mengingatkannya... ${ }^{2}$

\section{Pengertian Syahādah (kesaksian)}

Kesaksian dalam bahasa Arab disebut شهد- يشهد- شهآدة dari akar kata الثشآدة yang berarti; menyampaikan berita yang pasti, hadir dipersidangan, menyampaikan kesaksian, melihat dengan mata kepala, memberitahukan, dan bersumpah. ${ }^{3}$ Dari pengertian ini dapat disimpulkan bahwa kesaksian itu adalah memberitahukan tentang sesuatu yang disaksikan dan dilihat dengan mata kepala di depan hakim atas dasar keyakinan. ${ }^{4}$

Syahadah yang diambil dari kata (شهـ) yang memiliki makna melihat (رأي) sehingga ketika anda melihat susunan kalimat seperti (أنت رأيت فنشه) artinya anda benar-benar melihat dengan mata kepala anda sendiri. Dari pengertian ini dapat disimpulkan bahwa kesaksian seperti itu tidak membutuhkan kepada ilmu pengetahuan atau gelar akademisi seperti doktor atau magister. Karena yang dibutuhkan adalah kesaksian dengan mata kepala dan lebih ditekankan kepada kejujuaran. Sebuah kesaksian tidak membutuhkan analisis ilmiah, seorang saksi mata yang dibutuhkan adalah penglihatannya ketika melihat peristiwa baik dari kalangan akademisi ataupun bukan. Karena pada dasarnya mereka memiliki

\footnotetext{
${ }^{2}$ Kementerian Agama RI, al-Qur'ān dan Terjemahnya (Jakarta: Al-Hadi Media Kreasi, 2014) h. 70.

${ }^{3}$ Majma' al-Lughah al-'Arabiyah, al-Mu'jam al-Wasịt, (Kairo: Dār al-Ma‘ārif, 1972, Jilid 1, 497. Ibnu Manzūur, Lisān al-'Arab, Jilid 4, 226. Bandingkan al-Raghīb al-Aṣfahānī, Mu'jam Mufradāt al-Alfäz al-Qur'ān (Beyrut: Dār al-Fikr, 2010), 202

${ }^{4}$ Kesaksian itu harus memenuhi beberapa unsur yaitu : a. Dipastikan ada suatu perkara. b. Dalam obyek tersebut terdapat hak yang harus ditegakkan. c. Orang yang memberitahukan obyek tersebut menurut apa adanya. d. Orang yang memberitahukan benar-benar melihat atau mengetahui kebenaran obyek tersebut. e. Pemberitahuan tersebut disampaikan kepada pihak yang berwenang untuk menyatakan adanya hak bagi orang yang berhak. Badan Litbang Dan Diklat Departemen Agama RI, Kedudukan dan Peran Perempuan (Jakarta: Lajnah Pentashihan Mushaf al-Qur'ān, 2009), 280.
} 
kedudukan yang sama dalam memberikan kesaksian. ${ }^{5}$ Halikat kesaksian itu berdasarkan pengertian ini adalah memberitahukan tentang sesuatu yang disaksikan dan dilihat dengan mata kepala di depan hakim atas dasar keyakinan, tidak disyaratkan pendidikan dan kecakapan.$^{6}$

2. Analisis Ayat Kesaksian dalamTransaksi Utang Piutang.

فإن لم يكونا رجلين فرجل (و.774 H.) menafsirkan potongan ayat ini Kathï (w.7) (وامرأتان), bahwa kualitas kecerdasan dan agama kaum perempuan lebih rendah dari pada laki-laki. ${ }^{7}$ Penafsiran ini diperkuat dengan mengutip hadith Rasulullah saw.yang bersumber dari 'Abdullah ibn ‘Umar riwayat Bukhāri dan Muslim.

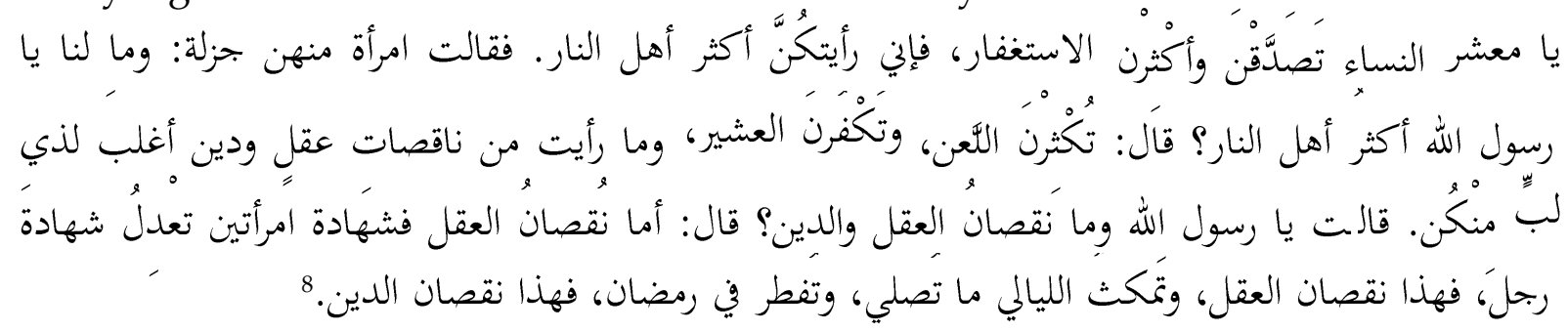

Wahai kaum perempuan! bersedekalah kamu dan perbanyaklah istigfar yaitu memohon ampun. Karena, aku melihat kaum perempuan lebih banyak menjadi penghuni neraka. Seorang perempuan yang cukup pintar di antara mereka bertanya: Wahai Rasulullah, kenapa kami lebih banyak menjadi penghuni neraka? Rasulullah saw. menjawab : Kamu banyak mengutuk dan mengingkari suami. Aku tidak melihat mereka yang kekurangan akal dan agama yang lebih menguasai pemilik akal, daripada golongan kamu. Perempuan itu bertanya lagi: Wahai Rasulullah! Apakah maksud kekurangan akal dan agama itu? Rasulullah saw., menjawab: Maksud kekurangan akal ialah penyaksian dua orang perempuan sama dengan penyaksian seorang laki-laki. Inilah yang dikatakan kekurangan akal. Begitu juga perempuan tidak mengerjakan shalat pada malam-malam yang dilaluinya kemudian berbuka pada bulan Ramadhan karena haid. Maka inilah yang dikatakan kekurangan agama. (HR.Bukha>riMuslim).

\footnotetext{
${ }^{5}$ Mutawalli al-Sha'rāwi, Fiqh al-Mar'ah al-Muslimah (terj.) Fikih Perempuan (Muslimah) Busana dan Perhiasan, Penghormatan atas Perempuan Sampai Wanita Karier (Jakarta: Amzah, 2009), 132-133.

${ }^{6}$ Kesaksian itu harus memenuhi beberapa unsur yaitu : a. Dipastikan ada suatu perkara. b. Dalam obyek tersebut terdapat hak yang harus ditegakkan. c. Orang yang memberitahukan obyek tersebut menurut apa adanya. d. Orang yang memberitahukan benar-benar melihat atau mengetahui kebenaran obyek tersebut. e. Pemberitahuan tersebut disampaikan kepada pihak yang berwenang untuk menyatakan adanya hak bagi orang yang berhak. Badan Litbang Dan Diklat Departemen Agama RI, Kedudukan dan Peran Perempuan (Jakarta: Lajnah Pentashihan Mushaf al-Qur'ān, 2009), 280.

${ }^{7}$ Abū al-Fidā' Ismā'il Ibnu Kathīr al-Qarshì al-Dimashq⿳亠丷, Tafsīr Ibnu Kathīr (Beyrut: Dār al-Fikr, 1986), Jilid 1, 336.

${ }^{8}$ Imam Muslim dan Imam al-Nawawī, Sahih Muslim bi Sharh al-Nawawī (Beyrut: Dār al-Kutub al'Ilmiyyah, t.th.), Jilid 2, 65-66. Hadith ini juga diriwayatkan Abu 'Abd Allah Muhammad bin Ismā'ill alBukhārī, Saḥị̣ Bukhārī, (Beyrut: Dār al-Fikr, 2008),Jilid 1, 78. Abū Dāwud Sulayman bin al-Ash'ath alSijistāni, Sunan Abū Dāwud (Beyrut: Mu'assah al-Kutub al-Thaqāifiyah, 1988), Jilid 2, 631. Abu 'Isa Muhammad bin ‘'Isa bin Sawrah, Sunan al-Tirmiżi (Beyrut: Dār al-Turath al-`Arabī, 1995), Jilid 5, 10.
} 
Menurut al-Qurtubī, kesaksian dua orang perempuan tetap harus bersama فرجل dengan seorang laki-laki, karena berdasarkan kaidah kebahasaan bahwa kata dan وامرأتان keduanya marfu' (dhamma) dan menempati posisi (kedudukan) mubtada', karena itu hukum yang melekat pada keduanya sama. ${ }^{9}$ Al-Qurt\}ubi membenarkan kesaksian dua orang perempuan khususnya dalam transaksi utang piutang, tetapi dengan syarat dua orang perempuan disertakan dengan seorang laki-laki tidak dibenarkan perempuan menjadi saksi sendirian.

Ibn 'Arabī berpendapat bahwa kesaksian perempuan setengah kesaksian lakilaki dalam persoalan hutang piutang, karena Allah mengutamakan laki-laki dari perempuan dalam enam hal: 1) Laki-laki adalah pokok sedangkan perempuan adalah cabang. 2) Perempuan diciptakan dari tulang rusuk laki-laki yang bengkok. 3) Perempuan kurang agamanya dan lemah agamanya. 4) Bagian dalam warisan kurang 2:1.5) Kurang tenaganya, lemah pisiknya. ${ }^{10}$

Kesaksian perempuan tetap menempati setengah kesaksian laki-laki dalam transaksi jual beli supaya jika salah seorang perempuan lupa maka yang lainnya dapat mengingatkan. ${ }^{11}$ Senada dengan 'Abd al-'Azīim Barawi, bahwa dalam transaksi utang piutang harus disaksiakan dua orang laki-laki atau seorang laki-laki ditambah dua orang perempuan. ${ }^{12}$

Al-Rāzi berpendapat bahwa kesaksian perempuan setengah kesaksian laki-laki karena tabiat kebiasaan perempuan lebih banyak bersifat dingin. Secara psikologis akan membuat mereka lupa dan lalai. Jika kesaksian perempuan tersebut dua orang secara logika mereka akan terhindar dari kelalaian tersebut. Kalau salah seorang di antara mereka lupa, maka yang lainnya dapat mengingatkan, sehingga kedudukan dua orang saksi perempuan sebanding dengan satu orang laki-laki. ${ }^{13}$

. Kata istisyhād: artinya minta kesaksian, maksudnya adalah perintah mendatangkan saksi setelah perintah pencatatan utang piutang, tujuannya adalah untuk meyakinkan dan sikap kehati-hatian dalam melakukan hakhak. Pencatatan dan kesaksian dua tugas bertemu pada satu orang, kadang-kadang salah seorang mencatat dan yang lainnya menyaksikan. ${ }^{14}$

فاءن لم يكونا رجلين فرجل و امر أتان ممن ترضون

Mengenai perbandingan persaksian, dua orang perempuan setara dengan satu orang laki-laki dalam ayat ini. Sayyid Qut\}b menyatakan bahwa dalam aqad

${ }^{9}$ Abū 'Abdullah Muḥammad Ibn Aḥmad al-Anșarī al-Qurțubi, al-Jāmi ' li Ahkām al-Qur'ān (Beyrut: Dār al-Kutub al-'Ilmiyah, t.th.), Jilid 1, 252.

${ }^{10}$ Abū Bakar Muhammad Ibn 'Abdullah Ibn 'Arabi, Aḥkām al-Qur'ān (Beirut: Dār al-Fikr, 1988), Jilid 1, 335.

${ }^{11} \mathrm{Abū} J a ' f a r$ Muhmmad Ibn Jarìr al-Ṭabarī, Jāmi' al-Bayān 'an Ta'wīl Ayy al-Qur'ān (Beyrut: Dār alFikr, 1988), Jilid 3, 125.

12، Abd al-'Az̄im bin Barawì, al-Wajiż fi Fiqh al-Sunnah wa al-Kitāb al- 'Azīz (Mesir: Dār Ibn Rahb li alNashr wa al-Tawzi', 2001), 476.

${ }^{13}$ Fakhruddin al-Rāzi, al-Tafsir al-Kabïr Mafātih al-Ghayib(Dār al-Fikr, t.th.), Jilid 7, 96.

${ }^{14} \mathrm{Abu}$ Muhammad 'Abd al-Hayy Ibn Ghālib ibn 'Ațiyyyah al-Andalusì,al-Muharrar al-Wajīz fi Tafsir al-Kitāb al-'Azīz (t.tp: Dār al-Fikr al-'Arabì, t.th.), Juz 2, 506. 
transaksi utang piutang harus ada dua orang saksi, kedua saksi itu adil dan diridhai di kalangan masyarakat. Akan tetapi dalam kondisi-kondisi tertentu yang tidak mudah mendapatkan dua orang saksi laki-laki. Maka, dalam kondisi seperti ini syariat memberikan kemudahan dengan menjadikan perempuan sebagai saksi. ${ }^{15}$

Lanjut Sayyid Quṭb menyatakan, syari'at menghendaki laki-laki, alasannya, karena biasanya merekalah yang aktif melakukan aktifitas di luar. Sementara, perempuan tidak perlu turut serta berkatifitas di luar karena akan menghilangkan keibuannya, kewanitaannya, dan akan mengganggu aktifitasnya dan kewajibannya dalam menjalankan tugas pokoknya yang lebih penting yaitu memelihara dan mendidik anak-anaknya. ${ }^{16}$

Argumen ini bisa diterima, mengingat masyarakat Arab ketika ayat ini turun, perempuan tidak diberikan kesempatan menjadi saksi karena dianggap tidak representatif. Di samping itu kemampuan profesional dalam soal transaksi bisnis sangat minim. Menurut Nasaruddin Umar sekarang tidak sulit mencari perempuan yang lebih expert daripada laki-laki, bahkan banyak perempuan tampil sebagai saksi ahli. Jadi masalah kualitas dan kuantitas persaksian dapat dipercayakan kepada lembaga peradilan. Lembaga peradilan sekarang seharusnya mengakomodir perubahan kualitas dan kuantitas masyarakat, sebagaimana dinyatakan dalam kaidah usul fiqh "al-hukmu yadu>ru ma'a al-illah" yakni hukum hendaknya mengikuti illat hukum, dan illat hukum selalu berubah seiring dengan perubahan masyarakat. ${ }^{17}$

Sayyid Qutb berargumen bahwa laki-laki yang dikehendaki dalam kesaksian, alasannya karena biasanya merekalah yang aktif melakukan aktifitas diluar. Sementara perempuan tidak perlu karena akan mengganggu kegiatan domestiknya. Alasan ini kurang tepat, keikutsertaan perempuan dalam kegiatan sosial sama sekali tidak menghalangi tugas-tugas kerumahtanggaan, apalagi menghilangkan keibuannya dan menjadi penghalang dalam menjalankan kewajibannya dalam pemeliharaan dan pendidikan anak-anaknya. Dalam konteks kekinian, banyak perempuan yang aktif dalam aktifitas bisnis (bisnis women) yang sukses, tanpa mengabaikan tugas-tugasnya sebagai ibu rumah tangga, sukses bisnisnya aman dan tenteram pula rumah tangganya.

Kurang akal pada perempuan yang disebutkan dalam hadith di atas mengandung beberapa makna:

1) Kekurangan alamiah yang bersifat secara umum.

2) Kekurangan alamiah dalam bidang tertentu yang membutuhkan kemampuan khusus yang tidak dimiliki oleh perempuan.

\footnotetext{
${ }^{15}$ Sayyid Quṭb, Fì Zilāl al-Qur'ān (Mesir: Dār al-Syurūq, 2011), Jilid 1, 335.

${ }^{16}$ Sayyid Quṭ, Fì Zilāl al-Qur'ān, Jilid 1, 335.

${ }^{17}$ Nasaruddin Umar, Ketika Fikih Membela Perempuan (Jakarta: PT, Gramedia, 2014), 203.
} 
3) Kekurangan insidental dalam bidang tertentu dalam jangka waktu pendek. Kekurangan ini secara alamiah terjadi sementara waktu akibat faktor insidentil dalam kondisi seperti siklus haid yang selalu dialami perempuan setiap bulan, masa nifas setelah melahirkan atau fase-fase kehamilan.

4) Kekurangan insidental dalam bidang tertentu dalam jangka waktu yang panjang. Kekurangan semacam ini muncul akibat berbagai kondisi kehidupan tertentu yang terjadi secara berkesinambungan, seperti kesibukan masa kehamilan, melahirkan, menyusui dan melahirkan anak. Aktifitasnya terbatas hanya terkuras dalam rumah tangga, sehingga terputus hubungan suasana di luar rumah yang mengakibatkan daya tangkapnya semakin lemah dalam memahami masalah sosial termasuk masalah keuangan. ${ }^{18}$

Menurut Nasaruddin Umar, secara sanad, kelihatannya hadith ini sahih karena diriwayatkan di dalam kutub as-sittah yang diakui dalam dunia sunni. Jika dicermati kekurangan akal dan agama perempuan dalam hadith ini bukan berasal dari dalam diri perempuan, karena masalah persaksian dan dispensasi untuk tidak menjalankan sejumlah ibadah tertentu adalah berasal dari luar diri perempuan. Dan persoalan banyaknya perempuan dalam neraka tidak berkaitan langsung dengan "kekurangan" dari faktor luar tadi. Boleh jadi, fenomena kelemahan perempuan di masa Nabi banyak dijumpai sehingga Nabi merasa perlu menyampaikan hadith semacam ini. Kemudian banyaknya perempuan dalam neraka tidak mesti diartikan perempuan lebih banyak di neraka dari pada laki-laki. Boleh jadi hadith ini disampaikan Nabi di depan komunitas perempuan dengan memperhatikan penggunaan kata ganti (damir) dalam hadith ini. Persoalan dosa dan neraka tidak berkaitan dengan jenis kelamin, sebagaimana disyaratkan dalam beberapa ayat alQur'a $>$ n. ${ }^{19}$

Hikmah perbandingan 2:1; khusus untuk jual beli yang tidak tunai karena kondisi perempuan yang tidak banyak aktif dalam bidang ekonomi seperti dalam keaktifannya dalam rumah tangga sehingga mereka dianggap kurang cakap dalam hal tersebut. Dengan demikian, perbandingan 2:1 tersebut bukanlah karena faktor kurang akal bagi perempuan. ${ }^{20}$

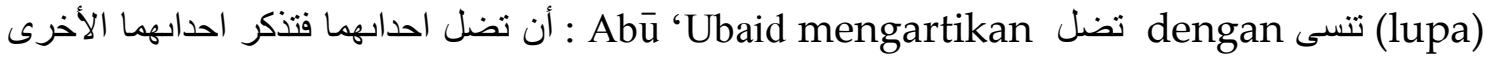
dari kesaksian. Maksudnya adalah lupa pada satu bagian dan ingat pada bagian lainnya. Seorang yang berada dalam keadaan ini akan bingung akhirnya tersesat. Adapun orang yang lupa secara keseluruhan maka ia tidak disebut dengan tersesat. ${ }^{21}$ Al-Naisaburì, تضل menurut bahasa (al-ghuyūbiyah) artinya kelalaian. Maksudnya salah

18 'Abd al-HaTim Abū Shuqqah, Tahrīr al-Mar'ah fì 'Aṣr al-Risālah (terj.) Kebebasan Wanita, Jilid 1, 275.

${ }^{19}$ Nasaruddin Umar, Ketika Fikih Membela Perempuan, 202.

${ }^{20}$ Ibn al-Jawziyah, I'lām al-Mawqi 'in 'an Rabb al- 'Alaminn (Beyrut: t.tp, 1973), Jilid 1, 95.

${ }^{21} \mathrm{Abū}$ Muḥammad 'Abd al-Hayy Ibn Ghalib Ibn 'Ațiyyah al-Andalusì, al-Muharrar al-Wajizz fí Tafsīr alKitāb al- 'Azìz (Dār al-Fikr al-'Arabì, t.th.) Juz 2, 511. Abu 'Abd Allah ibn Muhammad al-Anșāīi Al-Qurțubī, Tafsìr al-Qurtubī (Beyrut: Dār al-Bayān al-Turāth, t.th), Juz 2, 1205 
satu di antara keduanya lalai dari mengingatnya. Yakni salah satu dari keduanya mengingatkan kesaksian yang telah dibebankan kepadanya. ${ }^{22}$ Senada Ibrāhim Hāshim Ibrāhim, mengartikan نضل dengan "lupa." Jika salah seorang lupa tentang hakikat yang dipermasalahkan, maka salah seorang mengingatkannya. Jadi tidak termasuk apabila seorang perempuan sebanding dengan seorang laki-laki. ${ }^{23}$ Sementara menurut al-Shawkāni, ini adalah 'illah ditetapkannya kesaksian perempuan dua orang, karena hakekat 'illah ini adalah التذكير (mengingatkan). ${ }^{24}$

Senada dengan Wahbah al-Zuhaili mengakui bahwa illat penetapan hukum kesaksian perempuan setengah kesaksian laki-laki adalah al-tadzkï yang terdapat pada ayat tersebut dipahami bahwa perempuan kurang dhabit dan suka lupa sehingga dapat diingatkan oleh saksi perempuan lainnya. Kurangnya pengetahuan dan ingatan perempuan bukan karena sifat kemanusiaannya, tetapi karena realitasnya mereka kurang melakukan transaksi muamalah. Karena itu pengetahuannya terbatas dan sumber informasi yang diterima sangat minim. Saat ini perempuan sudah banyak terlibat dalam persoalan ekonomi tetapi hal itu tidak dapat merubah hukum karena hukum berlaku menurut kebiasaan secara umum. ${ }^{25}$

Sayyid Qut\}b menjelaskan bahwa kelupaan atau kekeliruan itu banyak sebabnya, antara lain: Pertama; Kadang-kadang karena minimnya pengetahuan (pengalaman) perempuan itu terhadap masalah transaksi. Sehingga ia tidak dapat memberikan kesaksian dengan jelas dan rinci ketika diperlukan, karena itu diperlukanlah orang lain agar saling membantu guna mengingat hal-hal yang sifatnya rumit itu. Kedua; kadang-kadang juga disebabkan oleh tabiat perempuan yang lebih emosional karena tugas keibuan secara biologis itu tentu memerlukan rasa kejiwaan. Sedangkan, kesaksian dalam transaksi utang piutang ini memerlukan orang yang lepas dari emosional, dan memfokuskan perhatiannya pada masalah yang sedang dihadapi dengan tidak terpengaruh oleh apapun. Dengan adanya dua orang perempuan diharapakan akan dapat memberikan jaminan dengan saling mengingatkan apabila salah satunya lupa karena pengaruh emosinya. ${ }^{26}$

Alasan yang dikemukakan Sayyid Quṭ kurang tepat, ketika ayat tersebut diturunkan kondisi perempuan kemungkinan belum berpengalaman dan belum terbiasa dalam masalah transaksi utang piutang. Jika dikatakan tabiat perempuan yang lebih emosional dalam melaksanakan tugas keibuannya, hal ini tidak mutlak berpengaruh terhadap kesaksiannya. Realitas saat ini sudah banyak perempuan yang berpengalaman dan bekerja secara profesional tidak mencampur baurkan

\footnotetext{
${ }^{22}$ Abu al-Husayn 'A Ali ibn Ahmad al-Wāhidì al-Naisaburī, al-Wasịt fì Tafsìir al-Qur'ān al-Majīd (Beyrūt: Dār al-Kutub al-'Ilmiyah, 1994), Juz 1, 404..

${ }^{23}$ Ibrāhim Hāshim Ibrahim, al-Mar'ah al-Muslimah wa Tawalliyahā al-Wazāif al-'Āmmāh Bayna al-Mu 'āradah wa al-Ta'yīdi (Kairo: Maktabah Wahbah, 2007, 148.

${ }^{24}$ al-Shawkāni, Fathul Qadir (Beyrūt: Dār al-Fikr.th.), Juz 1, 302.

${ }^{25}$ Wahbah al-Zuhaili, Tafsir al-Mnïr al-'Aqīdah wa al-Sharī'ah wa al-Manhaj (Beyrut: Dār al-Fikr, 1998), Jilid 3, 110-111.

${ }^{26}$ Sayyid Quṭb, Fì Zilāl al-Qur'ān, Jilid 1, 336.
} 
pekerjaan rumah tangga dengan pekerjaan di luar rumah tangga. Karena itu tidak benar jika dikatakan bahwa kesaksian perempuan dalam transaksi utang piutang harus dua orang karena perempuan itu pelupa akibat pengaruh tabiat emosionalnya, di samping itu tidak semua perempuan emosional, laki-laki dan perempuan samasama memiliki potensi lupa dan emosional.

Apabila dicermati sepintas penafsiran Sayyid Qutb terhadap ayat tentang transaksi utang piutang kelihatan tekstual, namun apabila dicermati tidak sepenuhnya tekstual. Hal ini tercermin ketika Sayyid Qut\}b menyebutkan illat hukum dalam ayat tersebut "jika salah seorang lupa, maka seorang lainnya mengingatkan.". Karena itu alasan-alasan yang dikemukakan tidak bersifat mutlak, ia hanya memberikan pernyataan sesuai dengan realitas yang terjadi dalam masyarakat ketika itu, yang sifatnya temporal dan kondisional. Ia juga tidak menyebutkan bahwa kesaksian perempuan 2:1 menjadikan perempuan lebih rendah nilainya dibanding dengan laki-laki karena kurang akal dan pelupa.

Nasaruddin Umar menjelaskan bahwa kata(من رجالكم) di atas, lebih ditekankan kepada aspek gender laki-laki, bukan kepada aspek biologisnya sebagai manusia yang berjenis kelamin laki-laki. Kenyataannya, tidak semua yang berjenis kelamin laki-laki mempunyai kualitas persaksian yang sama. Anak laki-laki di bawah umur atau laki-laki hamba, tidak termasuk di dalam kualifikasi saksi yang dimaksud dalam ayat tersebut. ${ }^{27}$ Masyarakat Arab ketika ayat ini diturunkan kaum perempuan tidak pernah diberikan kesempatan untuk menjadi saksi karena dianggap tidak representatif. ${ }^{28}$ Laki-laki yang bisa masuk kualifikasi saksi di sini adalah laki-laki yang sudah dewasa (balig) yang memiliki kualitas atau kemampuan, bukan semua laki-laki. Jadi yang menjadi syarat utama dalam persaksian adalah kualitas, karena itu perempuan dahulu tidak diberikan kesempatan menjadi saksi hanya karena dianggap kurang berkualitas.

Menurut Muhłammad 'Abduh, kesaksian seorang laki-laki sebanding dengan dua orang perempuan dapat dimaklumi, karena tugas dan fungsi perempuan ketika itu hanya disibukkan dengan urusan-urusan kerumah tanggaan, tidak disibukkan dengan urusan-urusan ekonomi, sehingga ingatannya dianggap kurang dalam masalah ekonomi, tetapi lebih kuat ingatannya dalam masalah urusan rumah tangga dari pada laki-laki. Sementara laki-laki bertugas untuk urusan-urusan sosial ekonomi di luar rumah. Bukannya perempuan lemah ingatan dan kecerdasannya

${ }^{27}$ Kata (min rijalikum) ialah orang Islam, merdeka, balig dan berlaku adil. Al-Zamakhsharī, al-Kashshāf 'an Haqāiq al-Tanzīl wa 'Uyūn al-Aqāwìl fì Wujūh al-Ta'wìl (Beyrut: Dār al-Fikr, 1977), Jilid 1, 403. Fakhr alDin al-Rāzìi, Tafsìr al-Kabìr wa Mafätih al-Ghayib (Beyrut: Dār al-Fikr li al-Ṭibā'ah wa al-Nashr wa al-Tawzi', t.th. Jilid 4,123. Al-Naisaburi kata sن رجالكم terdiri dari orang Islam merdeka, dewasa, tidak termasuk anakanak dan hamba. Abu al-Husayn 'Ali ibn Ahmmad al-Wāhidi al-Naisaburì, al-Wasìt fī Tafsīr al-Qur'ān al-Majīd (Beyrūt: Dār al-Kutub al-'Ilmiyah, 1994), Juz 1, 404. Bandingkan Abu Muhammad 'Abd al-Hayy Ibn Ghālib ibn 'Ațiyyah al-Andalusi, al-Muharrar al-Wajīz fi Tafsir al-Kitāb al-'Azīz, Juz 2, 502.

${ }^{28}$ Nasaruddin Umar, Ketika Fikih Membela Perempuan, 201. 
dibanding laki-laki. ${ }^{29}$ Muhammad 'Abduh sejalan dengan al-Marāghì, bahwa kesaksian perempuan harus dua orang berbanding kesaksian satu orang laki-laki mengandung hikmah (rahasia syar'i), yaitu kebiasaan yang berlaku saat itu bahwa perempuan tidak disibukkan dengan aktifitas urusan ekonomi. Karena itu ingatan mereka dalam masalah ini lemah, akan tetapi dalam masalah-masalah urusan rumah tangga ingatan mereka lebih kuat dibanding ingatan laki-laki, karena kekuatan pikiran manusia sangat dipengaruhi oleh sesuatu yang menjadi pusat perhatian dan keinginannya. Meskipun saat ini sudah banyak perempuan dalam dunia publik, hukum ini tetap berlaku dan tidak ada perubahan, karena hukum melihat sesuatu secara menyeluruh bukan parsial atau temporal. Sedangkan pada setiap masa, perempuan yang berkecimpung dalam dunia publik sangat sedikit jumlahnya, maka hukum kesaksian dua orang perempuan sama dengan kesaksian satu orang laki-laki tetap berlaku tanpa ada perubahan. ${ }^{30}$

Muhạmmad 'Abdụ dan al-Marāghì, keduanya melihat aktifitas yang biasa dilakukan perempuan pada saat turunnya ayat tersebut, keduanya tidak melihat pada sisi kederdasan dan intelektual seseorang, tetapi melihat kebiasaan rutin. Namun di sisi lain al-Marāghỉ ada pandangannya yang berbeda dengan gurunya. Ia melihat bahwa aktifitas rutin yang dilakukan masih berpengaruh dan akan selalu tertanam dalam benak seseorang. Lain halnya kegiatan yang tidak sering dilakukan tidak menjadi perhatian dalam ingatan seseorang bahkan boleh jadi lalai dalam hal itu atau ingatannya lemah dalam masalah itu.

Quraish Shihab melihat illat hukum di balik ketentuan ayat tersebut, menurutnya secara umum dapat dikatakan bahwa ketika ayat ini turun keterlibatan perempuan dalam persoalan perdagangan belum seperti dewasa ini. Keterlibatan perempuan yang kurang itu menjadikan perhatian mereka berkurang. Oleh karena itu, kemungkinan untuk lupa menjadi lebih besar dbanding dengan lai-laki yang selalu terlibat dan bergelut dengan perdagangan dan keuangan. Dengan demikian jika pesan ayat ini merupakan bagian dari lapangan ijtihad dianggap sebagai illat maka bisa saja untuk masa kini kesaksian langsung dalam bidang keuangan, dinilai sama dengan kesaksian laki-laki, yakni kesaksian perempuan yang telah banyak terlibat dalam pesoalan keuangan sama dengan kesaksian laki-laki. ${ }^{31}$

Ayat tersebut memang memberikan kualitas persaksian kepada perempuan masih sebatas satu berbanding dua dengan kualitas laki-laki, namun poin yang paling penting dalam ayat ini ialah pemberian pengakuan kepada perempuan untuk menjadi saksi yang sama sekali tidak pernah diperoleh sebelumnya. Ayat ini memberikan implikasi lebih jauh bahwa dengan pengakuan persaksian tersebut

\footnotetext{
${ }^{29}$ Muhammad'Abduh dan Rashīd Riḍā, Tafsìr al-Manār : Cairo: Dār al-Manār, t.th.), Jilid 3, 104. Bandingkan Ibrāhim Hāshim Ibrahim, al-Mar'ah al-Muslimah wa Tawallīhā al Wazāif al-Āmmah Bayna alMu'äradah wa al-Ta'yidd(Kairo: Maktabah Wahbah, t.th.), 147-148.

${ }^{30}$ Ahmad Muștafá al-Marāghì, Tafsìr al-Marāghì (Beyrut: Dār Ihya' al-Turath al-‘Arabī, t.th.), Juz 1, 75.

${ }^{31}$ M. Quraish Shihab, Perempuan Dari Cinta Sampai Sex Dari Nikah Mut'ah Sampai Nikah Sunnah Dari Bias Lama Sampai Bias Baru (Jakarta: Lentera Hati, 2005), 268.
} 
maka dengan sendirinya perempuan mendapatkan pengakuan untuk aktif di dalam dunia bisnis. Dengan kata lain, perempuan dimungkinkan untuk meniti karier di luar dunia domestik yang selama ini mengurungnya. Pemahaman secara kontekstual (bukan normatif) terhadap ayat di atas, karena dalam ayat-ayat lain tentang kesaksian tidak menyebutkan klasifikasi jenis kelamin. ${ }^{32}$ Dengan demikian ayat tersebut sejatinya dipahami secara kontekstual, bukan normatif. Karena ayat-ayat persaksian lainnya tidak satu pun yang membedakan jenis kelamin di antara ayatayat tersebut, yaitu ayat tentang wasiat orang yang akan meninggal yang hendaknya disaksikan oleh dua orang saksi, tanpa menyebutkan jenis kelamin tercantum dalam QS al-Maidah [5]: 106:

Ayat-ayat kesaksian lainya yaitu QS. al-Nisā' [4]: 15 tentang perbuatan keji, harus disaksikan 4 (empat) orang saksi, tidak disebutkan jenis kelamin, QS. alMaidah [5]:107 tentang ditemukan saksi curang, QS.al-Nur[24]:4 tentang tuduhan kepada perempuan yang berbuat keji harus disaksikan 4 (empat) orang saksi (tanpa menyebutkan jenis kelamin), QS. al-Nūr [24]:6 tentang tuduhan kepada istri yang berbuat keji, di mana istri tidak dapat mendatangkan empat orang saksi, maka sebagai gantinya harus bersumpah empat kali, dan QS. al-Ṭalāq [65]:2 tentang perempuan yang cerai setelah habis masa iddahnya, apakah ruju' atau pisah, maka didatangkan 2(dua) orang saksi.

Berdasarkan ketentuan tersebut dapat digaris bawahi bahwa saksi perempuan sama dengan saksi laki-laki. Tidak ada perbedaan di antara keduanya. Khususnya dalam masalah transaksi utang piutang, perempuan dapat menjadi saksi sendirian jika ia menyaksikannya sendiri, kendati jika ada perempuan lain hanya berfungsi sebagai pengingat (pendamping).

Muhammad Fadel menyatakan bahwa hukum Islam menetapkan kesaksian perempuan dikuatkan dengan seorang laki-laki dapat diterima terbatas hanya dalam masalah keuangan, dua orang perempuan senilai seorang laki-laki. Penetapan ini merupakan diskriminasi terhadap perempuan karena ruang publik dianggap ruang laki-laki. Dia mendukung pendapat Ibnu Taymiyah (w.728 H.) dan Ibnu Qayyim (w.751 H.) yang menolak aturan dua perempuan sama nilainya dengan satu laki-laki, karena terletak dijantung diskriminasi terhadap kesaksian perempuan. Diterimanya kesaksian tidak ditentukan oleh jenis kelamin melainkan ditentukan oleh kredibilitas, ketika seorang perempuan membuktikan kredibelnya maka hakim harus mengakui itu sama dengan mengakuinya kesaksian seorang laki-laki. ${ }^{33}$

Lain halnya Asghar Ali Engineer berpendapat bahwa kesaksian dua perempuan sebanding dengan kesaksian seorang laki-laki ini, dinilai bukan menunjukkan inferioritas perempuan, meskipun ayat ini, para fuqaha telah

\footnotetext{
${ }^{32}$ Nasaruddin Umar, Ketika Fikih Membela perempuan, 202.

${ }^{33}$ Muhammad Fadel, "Two Women, one Man: Knowledge, Power And Gender in Medieval Sunni Legal Thought," International Journal of Middle East Studies, Vol.29, No.2 (May 1997), 197-198. http//www.law.utoronto.ca.dokuments/lectures/religion-fadel-0710.pdf. (diaskes 15 Maret 2013).
} 
mendeduksikan satu aturan umum, yaitu satu saksi laki-laki setara nilainya dengan dua orang saksi perempuan. Tetapi semata-mata karena pada masa itu perempuan tidak mempunyai pengalaman yang memadai dalam masalah keuangan, oleh karena itu dua saksi perempuan dianjurkan oleh Al-Qur'ān. Dengan demikian bila terjadi kelupaan atau kesalahan, karena kurangnya pengalaman, maka salah seorang dapat mengingatkan yang lain. Karena laki-laki mempunyai pengalaman yang cukup, maka pengingat semacam itu tidak diperlukan bagi mereka. Disamping itu, fungsi perempuan yang lain hanyalah sebagai pengingat jika ia ragu terhadap kesaksiannya. $^{34}$ Dalam hal ini pengalaman laki-laki ketika itu berbeda dengan pengalaman perempuan. Jadi yang menjadi penilaian adalah faktor pengalaman bukan faktor kecakapan.

Lebih lanjut Asghar Ali Engineer menyatakan bahwa ayat di atas harus dipahami konteksnya, pada waktu itu kesaksian perempuan berjumlah dua orang lebih disebabkan perempuan belum banyak berpengalaman dalam bidang transaksi, dan kesaksian dua orang perempuan diperlukan guna menggantikan saksi laki-laki, karena apabila terjadi kelupaan, salah satunya bisa mengingatkan." Dalam praktiknya yang dimintakan kesaksian hanya seorang, yang lainnya hanya sebagai pengingat apabila terjadi kebimbangan atau karena kurangnya pengalaman, jadi bukan dipahami kesaksiannya bernilai setengah dari laki-laki atau kurang dari segi intelktualnya. ${ }^{35}$

Pandangan yang senada dikemukakan oleh Amina Wadud, bahwa adanya dua saksi pada waktu itu untuk menghindari pengaruh dominasi laki-laki terhadap perempuan karena jika seorang saja maka dapat dengan mudah dipengaruhi lakilaki (untuk berbuat curang), dan susunan ayat tersebut menjelaskan bahwa kedua perempuan tidak disebut keduanya menjadi saksi, karena berfungsi hanya sebagai pengingat yang bertindak sebagai teman kerja sama. ${ }^{36}$ Kedua tokoh feminis ini mengakui kesaksian dua orang perempuan nilainya sama dengan kesaksian satu orang laki-laki, namun hanya salah seorang yang menjadi saksi sementara lainnya berfungsi sebagai pengingat apabila terjadi kebimbangan dalam kesaksian, jadi bukan karena kurang dari segi intelektualnya.

\footnotetext{
${ }^{34}$ Asghar Ali Engineer, The Right of Women in Islam (India: ST.Martin's Press,1996), 63. Maḥmūd Shaltūt senada dengan Asghar bahwa, adanya perbedaan tersebut tidak menunjukkan bahwa perempuan lebih rendah dari laki-laki, tetapi sebagai sikap kehati-hatian, ketika salah satu perempuan lalai, maka yang satunya (lainnya) dapat mengingatkan, karena perempuan belum mempunyai keahlian dalam hal mu'amalah (transaksi keuangan) yang belum terbiasa mereka lakukan. Mạ̣mūd Shaltūt, Islam 'Aqidah wa Sharī'ah (t.t: Dār alQalām, 1996), 249. Ketentuan saksi laki-laki digantikan dengan dua orang perempuan bukan cerminan mengenai kemampuan intelektual perempuan lemah atau kurang secara mutlak, tetapi karena alasan fakta bahwa pada waktu itu perempuan kurang akrab dengan prosedur-prosedur bisnis dibanding dengan laki-laki, sehingga dikhawatirkan akan melakukan kesalahan dalam masalah ini. Muhammad Assad, The Massage of The Quran (London: Macmillan, 1980), 63.

${ }^{35}$ Ashgar Ali Engineer, The Right of Women in Islam, 64.

${ }^{36}$ Amina Wadud Muhsin, Qur'ān and Woman, (Kuala Lumpur:Fajar Bakti,SDN.BHD, 1994), 85-86.
} 
Mạ̣mūd Hamdi Zaqzūq (1933) menjelaskan bahwa yang berkaitan dengan persaksian (isyhad) yang termaktub dalam QS. Al-Baqarah (2):282) yang mensyaratkan adanya dua orang saksi perempuan, yakni agar bisa saling mengingatkan bila salah seorang terlupa, hal ini tidak berarti, bahwa perempuan adalah "mahluk pelupa," kealpaan merupakan tabiat yang inheren dalam setiap aktivitasnya. Sebaliknya, sifat lupa dan alpa ini lebih disebabkan oleh faktor-faktor yang berkaitan dengan kecakapan dan keterlatihan. Artinya persyaratan ini termasuk hal-hal yang bersifat insidentil dan dapat saja berubah. Dengan demikian, seorang perempuan yang dianggap memiliki kecakapan dalam ber-isyhad, maka persaksiannya dapat disamakan dengan laki-laki. ${ }^{37}$ Muṣtafā 'Abd al-Wālid menambahkan bahwa ayat ini tidak berarti kaum perempuan tidak dapat menjadi saksi sendirian, karena masalah kesaksian dapat dilakukan baik laki-laki maupun perempuan. $^{38}$

Analogi ini cukup logis, sifat lupa itu bukanlah sifat yang melekat pada perempuan, setiap manusia baik laki-laki maupun perempuan memiliki sifat lupa dan alpa. Kesaksian dua orang perempuan diperlukan dalam transaksi utang piutang, namun salah satunya hanya berfungsi sebagai pengingat jika terjadi kelupaan. Karena itu, memberi kesan bahwa jika tidak terjadi kelupaan salah satunya, maka tentu satu orang saja yang berfungsi menjadi saksi. Dengan demikian maka kesaksian perempaun setara dengan kesaksian laki-laki. Di samping itu dalam konteks kekinian tidak sedikit perempuan yang memiliki kecakapan terjun dalam bidang bisnis, menjadi manajer di perusahaan-perusahaan besar dan tidak sedikit yang menjadi saksi ahli. Karena itu dalam kondisi saat ini, kesaksian perempuan boleh disamakan dengan kesaksian laki-laki.

Argumen atas kesaksian dua perempuan sebagai ganti dari satu laki-laki adalah merupakan bentuk interaksi yang berhadapan secara langsung dengan masyarakat luas guna memberikan data akurat dan mengetahui kejadian yang sebenarnya. Sementara perempuan dalam skala mayoritas jarang sekali bersinggungan dengan hal ini, karena karakter perempuan pada dasarnya tidak bergumul dengan perihal persaksian. Bahkan dia sebenarnya tidak memiliki tali hubungan dengan praktik pemberian kesaksian. Kendati demikian apabila kesaksian perempuan diperlukan, maka harus diwakili oleh satu laki-laki ditambah dua perempuan. Hal ini didasari oleh fenomena ril perempuan yang memang karakter awalnya tidak berkecimpung dengan permasalahan ekonomi. Oleh karenanya, Allah menggantikan satu laki-laki dengan dua perempuan agar sikap timbal balik antara keduanya tumbuh dan berkembang dalam arti, ketika ia lupa maka perempuan yang lain mengingatkannya dan mengkaji ulang tindakannya tersebut.

${ }^{37}$ Maḥmūd Ḥamdi Zaqzūq, Haqāiq Islāmiyah fi ${ }^{-}$Muwājahāt Hamalāt al-Tashkīk (Kairo: Wizarāt alAwqāf al-Majlis al-A'lā li al-Shu'ūn al-Islamiyyah, 2005), 105.

${ }^{38}$ Muștafā ' Abd al-Wālid, al-Isāam wa al-Muskilah al-Jinayah (Kairo: Dār al-Isthishām, t.th.), 129. 
Penulis sepakat dengan pandangan yang menyatakan bahwa dua perempuan sebanding dengan satu laki-laki. Karena masyarakat Arab ketika ayat ini turun, perempuan tidak terbiasa terlibat dalam urusan ekonomi, sehingga pada masa itu perempuan kurang berpengalaman dalam masalah transaksi. Karena itu al-Qur'ān menganjurkan dua orang perempuan dan satu orang laki-laki agar salah satu mengingatkan, jika yang lainnya lupa atau lalai. Perempuan tidak banyak terlibat dalam kegiatan ekonomi (transaksi) kususnya jual beli adalah faktor kebiasaan dan pengalaman bukan faktor kekuatan ingatan atau kecerdasan dan intelektual seseorang. Karena laki-laki dan perempuan sama-sama berpotensi memiliki sifat lupa maupun cerdas.

Mengenai jumlah saksi dalam transaksi jual beli adalah dua orang laki-laki, atau seorang laki-laki ditambah dua orang perempuan dengan "illat" jika salah satunya lupa maka yang lainnya mengingatkannya. Pernyataan ini seolah-olah memandang bahwa perempuan adalah manusia pelupa, padahal kita melihat kenyataannya banyak juga laki-laki pelupa. Di zaman Nabi saw. memang tidak banyak perempauan terlibat dalam urusan ekonomi, mengingat perempuan ketika itu kebanyakan tidak senang dengan kegiatan ini jadi bukan karena mereka pelupa. Dalam konteks kekinian banyak perempuan yang cerdas terlibat dalam kegiatan ekonomi, sebagai menejer, direktur perusahaan dan selainnya. Artinya bahwa 'illat yang disebutkan sudah berubah, sebagaimana ahli Ushul Fiqh mengemukakan kaidah yang sudah populer di kalangan ahli hukum yaitu الحكم يدور مع العلة وجودا artinya hukum itu beredar berdasarkan ada atau tidaknya illat. Hukum mengikuti illat hukum, tidak ada hukum jika tidak ada illat hukum, kesaksian perempuan dalam transaksi jual beli, jika tidak ditemukan dua orang laki-laki, maka boleh saja satu orang laki-laki dan satu perempuan.

Apabila diamati konteks QS. al-Baqarah [2]:282] tersebut yang menyatakan bahwa kesaksian perempuan dua banding satu dengan laki-laki, dimaksudkan bukan sebagai persaksian yang berstatus hukum di hadapan hakim, tetapi hanya untuk mengukuhkan dan menenangkan hati dua pihak yang melakukan transaksi berkenaan dengan hak-hak mereka. Jadi kedudukan ayat tersebut sebagai penguat atas hak-hak pemilikan dan bukan berkenaan dengan urusan peradilan. Ayat tersebut tidak berarti bahwa kesaksian seorang perempuan atau kesaksian perempuan-perempuan tanpa bersama laki-laki, tidak bisa ditetapkan kebenaran dan tidak bisa dijadikan landasan bagi hakim, karena pada dasarnya yang menjadi tuntutan hukum adalah bukti nyata, sebagaimana disebutkan oleh Ibnu Qayyim (w.571 H.), bahwa bukti nyata dalam pandangan syara' lebih utama ketimbang persaksian. Karena itu, segala sesuatu yang bisa membuktikan kebenaran, maka ia

${ }^{39}$ Wahbah al-Zuhaili, Ușūl al-Fiqh al-Islamīi (Beyrut: Dār al-Fikr, 1992), Jilid 1, 651. Baca juga 'Abd alKarīm Zidān, al-Wajiz fỉ Ușū al-Fiqh (Beyrut: Mu'assasah al-Risālah, 1996), 203. 
merupakan bukti nyata yang biasa dijadikan landasan hukum untuk memutuskan suatu perkara. ${ }^{40}$

\section{KESIMPULAN}

Dalam kitab-kitab tafsir baik dalam kitab tafsir klasik maupun kitab tafsir modern dan kontemporer para mufasirnya sepakat bahwa perempuan mempunyai hak menjadi saksi dalam transaksi utang piutang sama dengan laki-laki. Namun mereka berbeda pendapat mengenai kuantitas saksi perempuan, mufassir klasik mengacu kepada pendekatan tekstual yakni dua orang saksi perempuan bersama satu orang laki-laki. Sementara mufassir modern dan kontemporer menggunakan pendekatan kontekstual, yakni bisa satu orang saksi perempuan bersama satu orang saksi laki. Mereka mengaitkan konteks sosio-historis al-Qur'an, juga dengan konteks masa kini. Mereka juga berpegang kpada kaidah Us\}ul Fiqh “al-hukmu yadūru ma'a al-illah wujüdan wa 'adaman. Kesaksian itu berdasarkan profesionalisme dan kredibilitas, tidak ada hubungannya dengan jenis kelamin. Dengan demikian jika perempuan mempunyai kecerdasan dalam bidang ekonomi maka kesaksiannya boleh disamakan dengan kesaksian laki-laki khususnya dalam kesaksian transaksi utang piutang, karena dalam ayat-ayat yang lain tentang kesaksian tidak menyebutkan klasifikasi jenis kelamin. ${ }^{41}$ Dengan demikian jika ayat tersebut dipahami secara kontekstual (bukan normatif), tentu akan melahirkan keadilan dan kesetaraan gender. Di samping, ayat tersebut hanya bersifat anjuran bukan wajib.

\footnotetext{
${ }^{40}$ Badan Litbang dan Diklat Depertemen Agama RI, Kedudukan dan Peran Perempuan (Tafsir al-Qur'ān Tematik), 289-290.

${ }^{41}$ Ayat-ayat kesaksian lainya tidak menentukan jenis kelamin, misalnya dalam QS. al-Nūr [24]:8 tentang tuduhan kepada istri yang berbuat keji, di mana istri dapat membatalkan sumpah suaminya. QS.al-Maidah [5]:106 kesaksian tentang wasiat bagi orang yang akan meninggal hendaknya disaksiakan dua orang saksi (tanpa menyebutkan jenis kelamin). QS.al-Nur[24]:4 tentang tuduhan kepada perempuan yang berbuat keji harus disaksikan 4 (empat) orang saksi (tanpa menyebutkan jenis kelamin) dan QS. al-Nisā' [4]: 15 tentang perbuatan keji, harus disaksikan 4 (empat) orang saksi, tidak disebutkan jenis kelamin. QS. al-Ṭalāq [65]:2 tentang perempuan yang cerai setelah habis masa iddahnya, apakah ruju' atau pisah, maka didatangkan 2(dua) orang saksi.
} 
